\section{Зорица Прњат}

Универзитет у Београду

Географски факултет
$316.77: 172.4$

https://doi.org/10.18485/filkult.2016.1.ch5

\title{
Језик и култура у доба друштвених медија
}

\section{Сажетак}

Настанак друштвених медија довео је до појаве активности и односа који су утицали на стварање новог обликајезика и културе. Може се рећи да култура друштвених медија утиче на готово сваки сегмент живота - на рад, одмор, забаву и друштвене односе, а језик друштвених медија на језик уопште. Савремене културолошке, комуниколошке и социолошке теорије истражују природу и далекосежност ових друштвених промена и процеса. У раду ћемо указати на неке од одлика језика и културе у доба друштвених медија, уз посебан осврт на језичку креативност и језичку норму.

Кључне речи: Друштвени медији, језик друштвених

Увод

Језик корисника друштвених медија првенствено одликује употреба великог броја жаргонизама који се захваљујући природи ових медија и начинима комуницирања веома брзо шире међу корисницима. Учесници у комуникацији путем друштвених медија истовремено креирају и усвајају нове изразе и управо ова спремност да језик прилагоде новонасталим друштвеним медијима чини основу „лингвистичке револуције“ (Прњат 2008, 49; Прњат 2014, 557). Дејвид Кристал $(2004,1)$ истиче да се глобалне језичке промене не дешавају често. Појава нових медија попут штампе, телефона и телевизије довела је до језичких промена, али се утицај интернета и посебно друштвених медија свакако може описати као најреволуционарнији.

Последњу деценију двадесетог и прву деценију двадесет првог века обележиле су значајне промене које су се догодиле на 
пољу лингвистике: енглески језик је постао први језик међународне комуникације, велики број угрожених језика се суочио са претњом изумирања и интернет и друштвени медији су се појавили као нова глобална комуникацијска технологија (Crystal 2004; Прњат 2014). Интерактивна природа друштвених медија фундаментално је променила начине комуницирања утичући како на језик уопште тако и на појединачне језике.

\section{Језик друштвених медија}

У књизи у којој се бави проучавањем језика интернета Language and the Internet, Кристал указује на чињеницу да највећи број корисника интернета широм света успева „веома брзо да прилагоди свој језик потребама новонасталих медија“ и да „на креативан начин гради нове форме изражавања“ (2001, 242). Сама природа комуникације путем друштвених медија подстиче креативност - брзина и лакоћа са којом се комуницира, пролазност и сажетост порука као и интерактивност чине да учесници у овом виду комуникације показују веома висок степен језичке креативности.

Питање језичке креативности у комуникацији на интернету разматра и Бренда Данет у књизи Cyberpl@y: communicating online и издваја пет основних фактора који утичу на креативност: (1) одлике компјутерски посредоване комуникације (брзина и интерактивност); (2) неспутана стваралачка енергија учесника; (3) природа сајбер простора као новог социјалног и културног 'Дивљег запада'; (4) утицај хакерске културе и (5) скривање идентитета (2001, 180). Многи истраживачи језика и културе интернета (Baron 1998, 2001, 2003; Crystal 2001, 2004; Danet 2001;) сматрали су сајбер простор осамдесетих и деведесетих година двадесетог века огромним, неоткривеним пространством без икаквих језичких, културних и правних норми, а хакере „компјутерским каубојима“ и „дигиталним истраживачима“ (Danet $2001,30)$. Међутим, временом се појављују први облици социјалне организације у комуникацији на интернету - уводе се правила за регулисање интеракције, али и казне за учеснике који их крше. Данас постоје утврђена правила комуникације у друштвеним медијима. 
Учесници у комуникацији на Фејсбуку, Твитеру, Инстаграму и другим друштвеним медијима знају како треба лајковати или хејтовати одређени садржај и када прекрше правила бивају кажњени. На пример, за женску особу која лајкује употребљава се именица која има неутралну конотацију лајкерка, док се за женску особу која лајкује готово сваки садржај само да би била запажена употребљава именица са негативном конотацијом - лајкуша, изведена додавањем „женског“ суфикса -уша, специјализованог за негативну карактеризацију жена као у именицама простакуша, дивљакуша, торокуша, флертуша, спонзоруша, намигуша итд. (Bugarski 2003, 5556; Prnjat 2013b, 134).

Наоми Барон износи мишљење да се језик интернета развијао на овакав начин због идеолошких померања која су се догодила у односу на писани енглески језик $(1998,1)$. Она наводи пример САД-а где све врсте писаног језика, не само оног који се јавља у комуникацији на интернету, показују тенденцију да буду мање формалне, што је последица промена које су се догодиле у америчком образовном систему у претходних стотинак година. Наиме, у оквиру основношколског и средњешколског система образовања у САД-у, стари наставни план, који се заснивао на настави граматике, правописа и књижевности, замењен је новим планом чију основучини креативно писање. (Baron 2003, 88). Ово је, како Баронова закључује, учинило да нове генерације говорника америчког енглеског језика, што се може рећи и за друге дијалекте енглеског, све мање брину о језичким правилима и њиховој примени. Она овакав слободан однос према језичким правилима назива „језичким штогодизмом“ (linguistic whateverism) (Прњат 2014, 560).

Социолингвистичка истраживања (Džouns 2001) показују да учесници у комуникацији путем друштвених медија деле заједничке лингвистичке особине стечене прихватањем језичких одлика осталих учесника у комуникацији. Стога не треба да чуди што је са појавом интернета и друштвених медија дошло до пораста утицаја енглеског на друге језике (Прњат 2014, 560). Олга Панић-Кавгић указује на чињеницу да је путем друштвених медија енглески језик стекао апсолутну доминацију у међународној комуникацији постепено продирући у „све регистре писане и говорене комуникације стотина 
других језика“ $(2006,17)$. Тако суу српски језик ушли англицизми попут: твит, твитовање, твитераш, твитерашица, твитовати, ретвитовати, твитерашки, лајк, лајковње, нелајковање, лајкер, лајкерка, лајкуша, лајкерски, хејт, хејтовање, хејтер, хејтерка, хејтерски, фоловати, анфоловати, фоловер, фоловерка, френд, френдовати, анфрендовати и многи други (Prnjat 2013b, 133-135). Из наведених примера може се видети да је највећи број ових позајмљеница, које представљају жаргонизме језика друштвених медија, добро уклопљен у систем српског стандардног језика (акценатски и морфолошки).

Ранко Бугарски у књизи Језик и култура $(2005,210)$ каже да “... суштину жаргона и главни разлог његовог постојања представља потреба чланова неке друштвене групе да и специфичним вербалним средствима афирмишу свој идентитет и потврде своју припадност датој групи". Друштвене групе се могу разликовати по професији, социјалном статусу, узрасту и сл., а њихов жаргон је обележен специфичним језичким средствима, пре свега лексичким и фразеолошким, а изузетно и граматичким и фонолошким (Bugarski 2003, 9). Жаргон друштвених медија заступљен је највише у језику урбаних, донекле двојезичних припадника млађе генерације, који одрастају уз друштвене медије и који своју језичку културу стичу управо путем ових медија и код одређених занимања везаних за друштвене медије попут, на пример, професионалних блогера (Прњат 2014, 561). Различите културе различито реагују на прилив англицизама и у оквиру самих култура постоје супротстављени ставови: док једни, најчешће представници млађих генерација, поздрављају утицај енглеског на свој матерњи језик сматрајући да се на тај начин њихов језик лексички обогаћује, други га осуђују сматрајући да неконтролисани прилив позајмљеница представља опасност по њихов језик (Prćić 2011, 77-79). Брз развој информационе технике и интернета условио је појаву многобројних нових уређаја и процеса који су са собом донели и нове називе попут ајфон, ајпед таблет, блог, твит, селфи и сл. Стога су енглески називи постали глобално прихваћени и у оним језичким заједницама које су до скоро биле затворене за језичка позајмљивања (француски или немачки језик). Истраживања су показала (Panić-Kavgić 2006; Prćić 2005; Vasić, Prćić i Nejgebauer 2001; Марковић, Прњат и Басарић 2014) да се српски језик показао као један од најотворенијих према преузимању англицизама. 


\section{Култура друштвених медија}

Развој друштвених медија учинио је да енглески језик утиче не само на матерње језике говорника различитих нација који су у контакту са њим, већ и на њихову културу и обрасце понашања (Prnjat 2013b, 127). Занимљива је чињеница да могућност анонимног комуницирања на друштвеним медијима представља важан фактор који утиче на стваралачки однос када је језик у питању али и на обрасце понашања. Од свих интернет ситуација виртуелни светови и друштвенимедијипоказујунајвишистепен ,карневалскогмаскирања“ јер пружају највише могућности за прикривање идентитета (Прњат $2014,558-559)$. Учесници у комуникацији могу употребити надимке или псеудониме, а одсуство социјалних знакова идентитета чини да постану слободнији и да се понашају на нове начине. Истраживања социјалних аспеката комуникације путем друштвених медија указала су на чињеницу да учесници у комуникацији показују израженију тежњу ка само-откривању (self-disclosure) у поређењу са комуникацијом лицем у лице или путем телефона (Baron 1998; Danet 2001; Ma, Hancock and Naaman 2016). Наиме, социјални психолози су већ раније приметили да непостојање визуелних знакова (нпр. код комуникације путем телефона) значајно повећава степен до кога су саговорници спремни да се „отворе“ тј. да разговарају о темама о којима би можда оклевали да проговоре у комуникацији лицем у лице. Због смањеног присуства визуелних и звучних знакова који би указивали на социјални статус учесника у комуникацији, учесници ступају у међусобне интеракције слободније него у комуникацији лицем у лице. Овакав отворенији однос примећен је у свим врстама комуникације путем друштвених медија и међу свим корисницима без обзира на пол, старосну доб, социјални статус, професију итд. (Прњат 2013а, 52). Такође, истраживања (Baron 2001, 234; Džouns 2005, 49-50) су показала да људи дају тачније и потпуније информације о себи у ситуацијама када попуњавају упитнике на интернету, него када то чине у комуникацији лицем у лице, путем телефона или у традиционалној писаној форми.

Социолингвисти се слажу да се култура сајбер простора може посматрати двојако: као монолитна појава - учесници у комуникацији се понашају на исти начин, користе исти језик (обележен жаргонизмима), 
поштују исте норме, изражавају иста схватања, имају иста интересовања и сл., али и као потпуно нејединствена појава - свака чет група, виртуелна заједница или група при неком од друштвених медија развија своју сопствену субкултуру која се битно разликује од културе других група. (Џоунс 2001, 32-34; Данет 2001, 35; Прњат 2013а, 53).

\section{Литература}

Baron, Naomi. "Writing in the age of email: the impact of ideology versus technology." Visible Language 32 (1998): 35-53.

Baron, Naomi. Alphabet to email: How Written English Evolved and Where It's Heading. London: Routledge, 2001.

Baron, Naomi. "Why email looks like speech: proofreading, pedagogy and public face." New Media Language. Ed. Jean Aitchinson and Diana M. Lewis. London: Routledge, 2003. 85-94.

Bugarski, Ranko. Žargon: lingvistička studija. Beograd: Čigoja, 2003.

Bugarski, Ranko. Jezik i kultura. Beograd: Čigoja, 2005.

Vasić, Vera, Tvrtko Prćić i Gordana Nejgebauer. Do yu speak anglosrpski? Rečnik novijih anglicizama. Novi Sad : Zmaj, 2001.

Danet, Brenda.Cyberpl@y: Communicating Online. Oxford: Berg, 2001.

Crystal, David. Language and the Internet. Cambridge: CUP, 2001.

Crystal, David. The Language Revolution. Cambridge: CUP, 2004.

$\mathrm{Ma}$, Xiao, Jeff Hancock and Mor Naaman. „Anonymity, Intimacy and Self-Disclosure in Social Media". Proceedings of the 2016 CHI Conference on Human Factors in Computing Systems. San Jose, California, The Association for Computing Machinery, 2016: 3857-3869.

Марковић, Љиљана, Зорица Прњат и Јелена Басарић. „Англицизми у стручној терминологији: пример менаџмента и маркетинга у туризму." Наука и глобализација - Филолошке науке, Књига 8, том 1/1. Пале: Филозофски факултет, Универзитет у Источном Сарајеву, 2014: 45-53.

Panić-Kavgić, Olga. Koliko razumemo nove anglicizme. Novi Sad: Zmaj, 2006.

Прњат, Зорица. „Језичка револуција“. Интервју са Дејвидом Кристалом. НИН, 13.новембар 2008.

Прњат, Зорица. Језик имејла. Речи V, 6, (2013а): 44-54.

Prnjat, Zorica."PLS Lajkuj moj STS: anglicizmi u jeziku korisnika društvene mreže Tviter." Примењена лингвистика 14 (2013b): 127-137.

Прњат, Зорица. „Језик и култура у сајбер простору.“ Географско образовање - наука и пракса: развој, стање и перспективе. Ур. Грчић, Мирко, Дејан Филиповић и Славољуб Драгићевић. Београд: Географски факултет, Универзитет у Београду, 2014: 557-562. 
Prćić, Tvrtko. “English as the Nativized Foreign Language Revisited: Some Glocal Implications. Image_Identity_Reality. Ed. Biljana Đorić-Francuski. Cambridge: Cambridge Scholars Publishing, 2011: 75-82.

Prćić, Tvrtko. Engleski u srpskom. Novi Sad: Zmaj, 2005.

Džouns, Stiven. Virtuelna kultura: identitet i komunikacija u kiber društvu. Beograd: XX vek, 2001.

\section{Zorica Prnjat}

University of Belgrade

Faculty of Geography

\section{LANGUAGE AND CULTURE IN THE AGE OF SOCIAL MEDIA}

\section{Summary}

The emergence of social media brought about activities and social relations that led to creation of a new form of language and culture. We can say that the culture of social media affects almost every aspect of our life - professional, family and social relations, whereas the language of social media influences language in general. Contemporary cultural, communication and sociological theories explore the nature and long-term consequences of these social changes and processes. In this paper, we present some of the features of language and culture in the age of social media, with special emphasis on linguistic creativity and linguistic norm.

Key words: Social media, social media language, social media culture 